16. スピードスケート逗轩の体格及ひ体力について

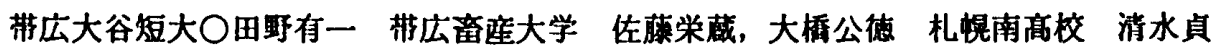

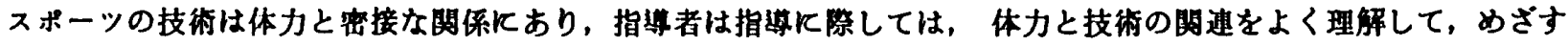

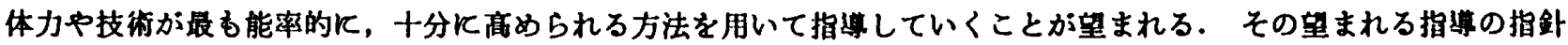

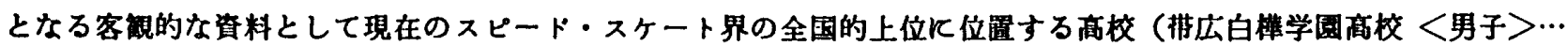

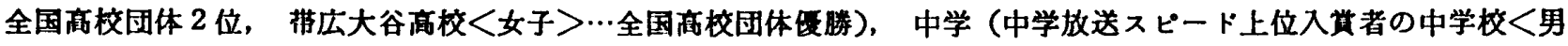

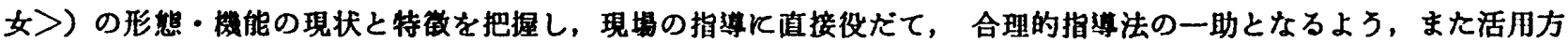

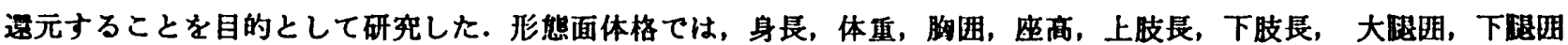

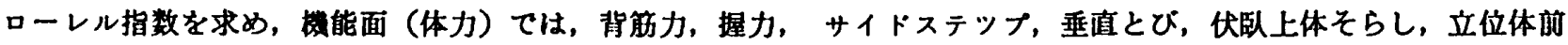

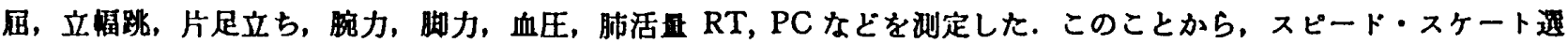

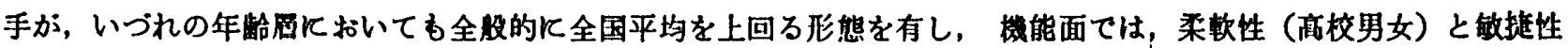

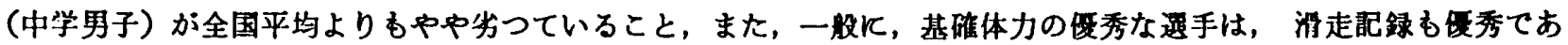
ること‥等がかかつた. スピード・スケートは，数多くのメカニズムの上K立つた䫓技である．本研究を，それらの

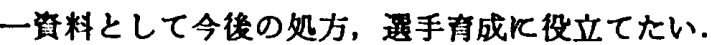

\title{
17. アイス・スケートにおける初步技術に関する研究一(滑走時における面心閶保)
}

広島大学O勝 谷 茂

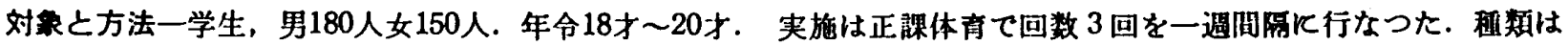

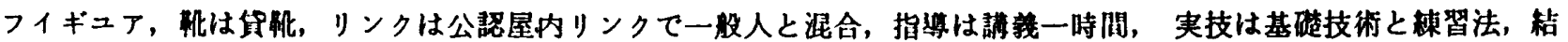
果の記録は条作設定汇対し被䮖者自身が行なつた。スケート経駼内容は男女共未経駼者 $34.3 \%$ ，他は省略.

\section{耛果と考察}

1. 正進消走時におけるブレードの重心

(1)前後の重心状㤎は，男％前方35.0中央34.2後方15.6不明152.女\%前方31.6中央24.9. 後方14.0不明29.5であり， 前が多く後が少ない，但し，経駼が增すとつれ中央，後方が多くなり，不明が娍少する。

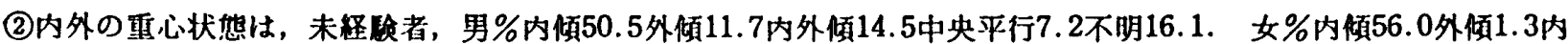

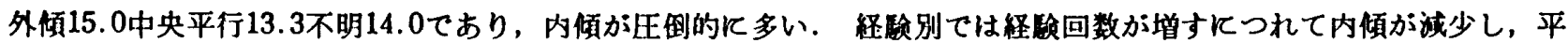
行が多くなり，不明が娍少する。

2. 西進滑走時水打りる足の重心

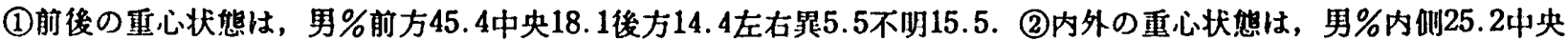
47.7外側5.4であり中央が特飞多い.女子Kおける(1)(2)男子と類似の䊁果を示した.

3. 足の重心とブレードの重心闺係前後の重心関係

は両者が一致する者が多い，橫（内中外）は必ずしも一致していない．

18. ゲループ䋗成における成員選択の理由（第1報 小学校）

北陸支部○森田克, 山下三郎, 田中久雄

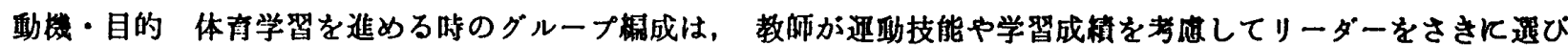

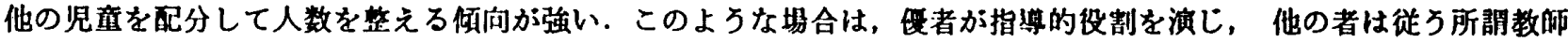
の都合のよいグループとなる.

児童の自由時の仲間作りとみられる気の合つた者・人気のある者を選ぶなどの選択の姴素を加味すれは，グルーフ 成員それぞれの力を発拥するよいグループが作れると考える。

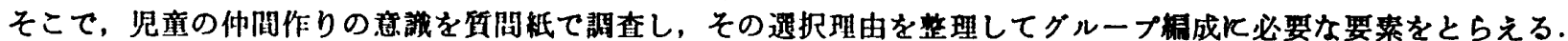

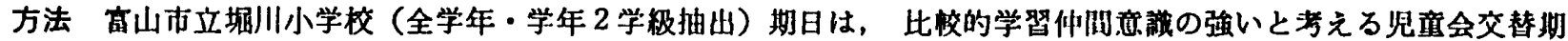

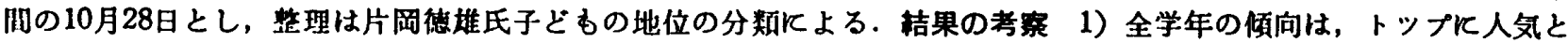
なり $36 \%$ ，以下成秙は $27 \%$ ，学習活動は $13 \%$ ，生活は $11 \%$ ，学校文化歴の $3 \%$, その他は $10 \%$ の意諹を示した.

2) 選択要素別では (1)人気は 1 年・2 年から濑次增加 (2)成縝は 2 年生で急增し以下同率, (3)生活は $1 \cdot 2$ 年の20 \%から $5 \%$ 位滛娍する. 予想外の低率は，学校文化歴であつた。

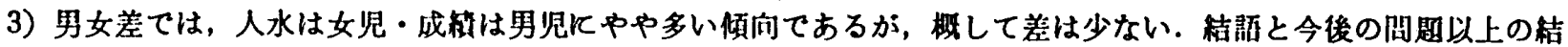

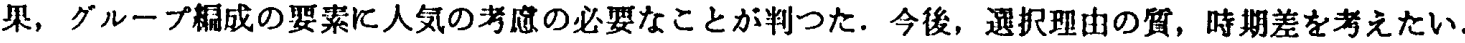

